\title{
CKR-L3, a deletion version CCR6-isoform shows coreceptor-activity for limited human and simian immunodeficiency viruses
}

\author{
Salequl Islam", Nobuaki Shimizu, Takahiro Ohtsuki, Atsushi Jinno-Oue, Atsushi Tanaka, Hiroo Hoshino \\ From Abstracts from International Symposium HIV and Emerging Infectious Diseases 2014 \\ Marseille, France. 21-23 May 2013
}

\section{Background}

Chemokine receptors (CKRs), CCR5 and CXCR4 function as major coreceptors in human/simian immunodeficiency virus (HIV/SIV) infections. About 20 alternative G protein-coupled receptors (GPCRs) have been identified as minor coreceptors for the viruses. We reported CCR6 as an alternative coreceptor. A five-amino acid shorter isoform of CCR6, namely CKR-L3, was examined for its coreceptor function and described in this report.

\section{Methods}

NP-2 cells transduced with CD4-receptor (NP-2/CD4) normally remain resistant to all HIV/SIV infection; however, further introduction of functional coreceptor can make the cells susceptible to the viruses. NP-2/CD4/CKR-L3 cells were produced to examine coreceptor activity of CKR-L3. Viral antigen in infected NP-2/CD4/coreceptor cells was detected by indirect immunofluorescence assay (IFA). The results were validated by detection of syncytia, proviral DNA and by measuring reverse transcriptase (RT) activities.

\section{Results}

HIV-2MIR and SIVsmE660 were found to infect NP-2/ CD4/CKR-L3 cells. This justifies the coreceptor function of CKR-L3. Viral antigens appeared faster in NP-2/CD4/ CKR-L3 cells than in NP-2/CD4/CCR6, indicates that the CKR-L3 carries more efficient coreceptor-activity. Moreover, syncytia formation was sooner, RT release was higher and earlier through CKR-L3 compared to CCR6. Partial sequence analyses of HIV-2MIR and SIVsmE660 replicated through CKR-L3 and CCR6 coreceptor showed some divergence in envelope region compared to the parental CCR5-variant.

Johns Hopkins University, Baltimore, USA Attribution License (http://creativecommons.org/licenses/by/4.0), which permits unrestricted use, distribution, and reproduction in any medium, provided the original work is properly cited. The Creative Commons Public Domain Dedication waiver (http:// creativecommons.org/publicdomain/zero/1.0/) applies to the data made available in this article, unless otherwise stated. 
towards CKR-L3-use. CKR-L3 with other minor coreceptors may contribute to HIV/SIV pathogenesis including dissemination, trafficking and latency.

Published: 23 May 2014

doi:10.1186/1471-2334-14-S2-P69

Cite this article as: Islam et al:: CKR-L3, a deletion version CCR6-isoform shows coreceptor-activity for limited human and simian

immunodeficiency viruses. BMC Infectious Diseases 2014 14(Suppl 2):P69.

Submit your next manuscript to BioMed Central and take full advantage of:

- Convenient online submission

- Thorough peer review

- No space constraints or color figure charges

- Immediate publication on acceptance

- Inclusion in PubMed, CAS, Scopus and Google Scholar

- Research which is freely available for redistribution 